\title{
The Development of a New Water Code in the Republic of Kazakhstan
}

\author{
Mariya Genina
}

Northern Arizona University

mvg9@nau.edu

The new Water Code (WC), adopted in the Republic of Kazakhstan (RK) in 2003, has not been sufficiently enforced. This has led to the water quality degradation and shortages. This paper identifies the factors leading up to the development of the WC and reasons for its weak enforcement. Using open-ended interviews and a an analysis of archival information, this paper examines the reduction of financing and a weakening institutional capacity of the water organizations as main reasons for water quality degradation. These factors, plus unfamiliarity with the international terminology and inconsistency with other legislative acts are presented as key causes for the poor WC enforcement. The future of the water resources in Kazakhstan depends upon the effectiveness of future capacity building efforts.

The new Water Code (WC) of the Republic of Kazakhstan was adopted in 2003. Together with a series of regulatory acts, the WC provides a legislative basis for water related decisionmaking in the country. The main goal of the new WC was to achieve and maintain an environmentally safe and economical efficient level of water use, and to provide water resource protection that preserves and improves the living conditions of citizens and the status of the environment (Water Code, art. 3, 10 (as cited in Salman 2006)). Moreover, the new WC introduced international standards for equitable access to water and authorized the concept of integrated water resources management (IWRM) in Kazakhstan.

Some argue that the new WC was successful in terms of water management regulation and forwarding environmental interests, such as the protection of water quality and watershed management (Petrakov et al. 2006). However, many water policy experts assert that enforcing the WC faces huge obstacles, including institutional fragmentation, conflict with other laws and codes, and low capacity of executive water management institutions (Mitrofanskaya 1999; OECD 2000). The failure to implement the 2003 WC is one of the most significant reasons for current environmental problems such as severe pollution of water bodies, extensive desertification of agricultural lands, significant decreases in crop production, deteriorating water infrastructure, and low access for the population to safe drinking water and sanitation (UNDP Project 2005).

Despite current literature indicating that WC enforcement faces significant challenges (Mitrofanskaya 1999; OECD 2000), few analyses (Zimina 2002) exist on the reasons for these challenges and the initial process of Code's development. This research analyzes the history 
and context of the WC development and examines factors influencing enforcement of the new Water Code.

Some policy analysts describe that in the period between the previous Water Code and the adoption of a new one, from 1993 to 2003, Kazakhstan experienced significant changes in its socio-economic, environmental and political situation, which necessitated the development of new water legislation. Despite various policy experts' awareness of the current situation, the driving factors and the initial process for WC creation and adoption remain unexamined. In this respect this paper addresses the following questions: Why was the new water law necessary in Kazakhstan? Which stakeholders were involved in the Code's development and adoption processes? Ultimately, do features of WC development process affect its presentday enforcement process?

\section{Methodology}

The methods for this research consist of a review of published literature, mass media publications, reports from national and international organizations, and structured openended interviews with the main authors of the WC and local water policy experts. The water legislation reforms were assessed with a wide perspective, focusing on the influence of various stakeholders and the law-making process.

\section{Historic overview of water resource management}

Water regulation and management is the most significant issue in Central Asia (Jalling 2003). Root causes for fragmented and inefficient water regulation lie both in the Soviet "environmentally disastrous policies and practices" (Jalling 2003), and a lack of attention to water resources after the fall of the Soviet Union. The consequences of these policy failures for the environment have been very destructive.

After the collapse of the Soviet Union, all Central Asian countries developed their own water legislation. The first Kazakhstan national Water Code was adopted in 1993. It reflected the Soviet water regulatory mechanisms that functioned for the previous 65 years and was characterized by highly centralized and stagnant mechanisms (Jalling 2003). Irrigation is one example. In the 1960s the Soviet government constructed huge irrigation systems in Central Asia covering hundreds of thousands of hectares. It was impossible to irrigate those huge fields uniformly, so excessive volumes of water had to be applied. This led in turn to soil erosion, rising groundwater levels, waterlogging, secondary salinisation, increased water use and lower crop yields. After the fall of the Soviet Union, the Central Asian states were left with huge interdependent irrigation systems and deteriorating water resources (Jalling 2003; Mickin 2000; UNDP 2004).

Soon after 1993, it became clear that the WC was inappropriate for the new independent environment. Because of the ineffectiveness and irrelevance of the old WC, and rapid economic, social and political changes in 1990s, a new WC was adopted in Kazakhstan in 2003 with the aim of improving the water resources regulation and status of the environment. 


\section{Water resources in Kazakhstan}

The Republic of Kazakhstan is situated in Central Asia, occupying 2.72 million $\mathrm{km}^{2}$ of land, ranking as the ninth largest country in the world. Kazakhstan has an extremely diverse landscape, $58 \%$ is deserts and semi-deserts and around 10 percent is mountains. An important feature of Kazakhstan water resources is that the majority of the rivers originate in neighboring countries, Kyrgyzstan and Tajikistan, which makes an issue of water resource management and water quality very challenging (UNDP 2004).

The average water resources per year in Kazakhstan is estimated to be $100.5 \mathrm{~km}^{3}$. The distribution of water is $37,000 \mathrm{~km}^{3}$ per $\mathrm{km}^{2}$ and $6,000 \mathrm{~m}^{3}$ per person per year. These indicators are the lowest in the Commonwealth of Independent States (CIS). International standards indicate that annual supply of $8,000 \mathrm{~m}^{3}$ per person is adequate. The water provision inside Kazakhstan varies significantly by region. For example, the basin of the Irtysh River (East Kazakhstan oblast) is considered a well-provided region; while the Ural-Caspian basin (Mangistau oblast), is a water deficit area (UNDP 2004). Although the natural factors, like the uneven distribution of surface waters and the annual and seasonal river flow fluctuations, contribute to Kazakhstan water resources shortage, the more important reasons for water problems are poorly regulated trans-boundary water relations with neighboring countries, and highly inefficient water use for irrigation (UNDP 2004). According to UNDP 2005 , overall irrigation efficiency in Kazakhstan is less than 60\%, resulting in that around $40 \%$ of water, devoted to irrigation is lost in the irrigation network and fields. Moreover, $70 \%$ of available surface water resources in the country, consumed for irrigation, contribute only $10 \%$ of the total economy of the country.

This inefficiency in irrigation of the country leads to water salinisation and severe levels of desertification (Jalling 2003; UNDP 2004). The water quality deterioration results in increasing number of water born diseases, ecosystem destruction and increasing potential for trans-boundary river conflicts. The most dramatic consequence of wasteful irrigation in the region is the near disappearance of the Aral Sea. Approximately $60 \%$ of the lake's surface has sunk by almost $80 \%$ for the period from 1960 to 1990s and now the Aral Sea currently consists of two parts, the North and the South Aral Seas (Jones 2003).

Not only does the irrigation inefficiency result in water losses and ecosystems degradation, it also results in considerable economic losses. Lost water can be translated into forgone crops. According to UNDP (2005), annual losses to Kazakhstan due to reduced crop yields alone are estimated at KZT 27 billion (\$US 200 million).

The present water management system in Kazakhstan is based on the basin principle. The territory of Kazakhstan is divided into 8 hydro-economic basins: Aral-Syrdarya basin, Balkhash-Alakol basin, Irtysh basin, Ural-Caspian basin, Ishim basin, Nura-Sarysu basin, ShuTalas basin and Tobol-Turgai basin (see Figure 1, overleaf).

\section{Factors in the development of Water Code}

The existing literature and interviews with WC developers agree on several factors that predetermined the development of the WC. The factors can be divided into five interdependent categories: financial, legal, social, political and institutional. The literature 


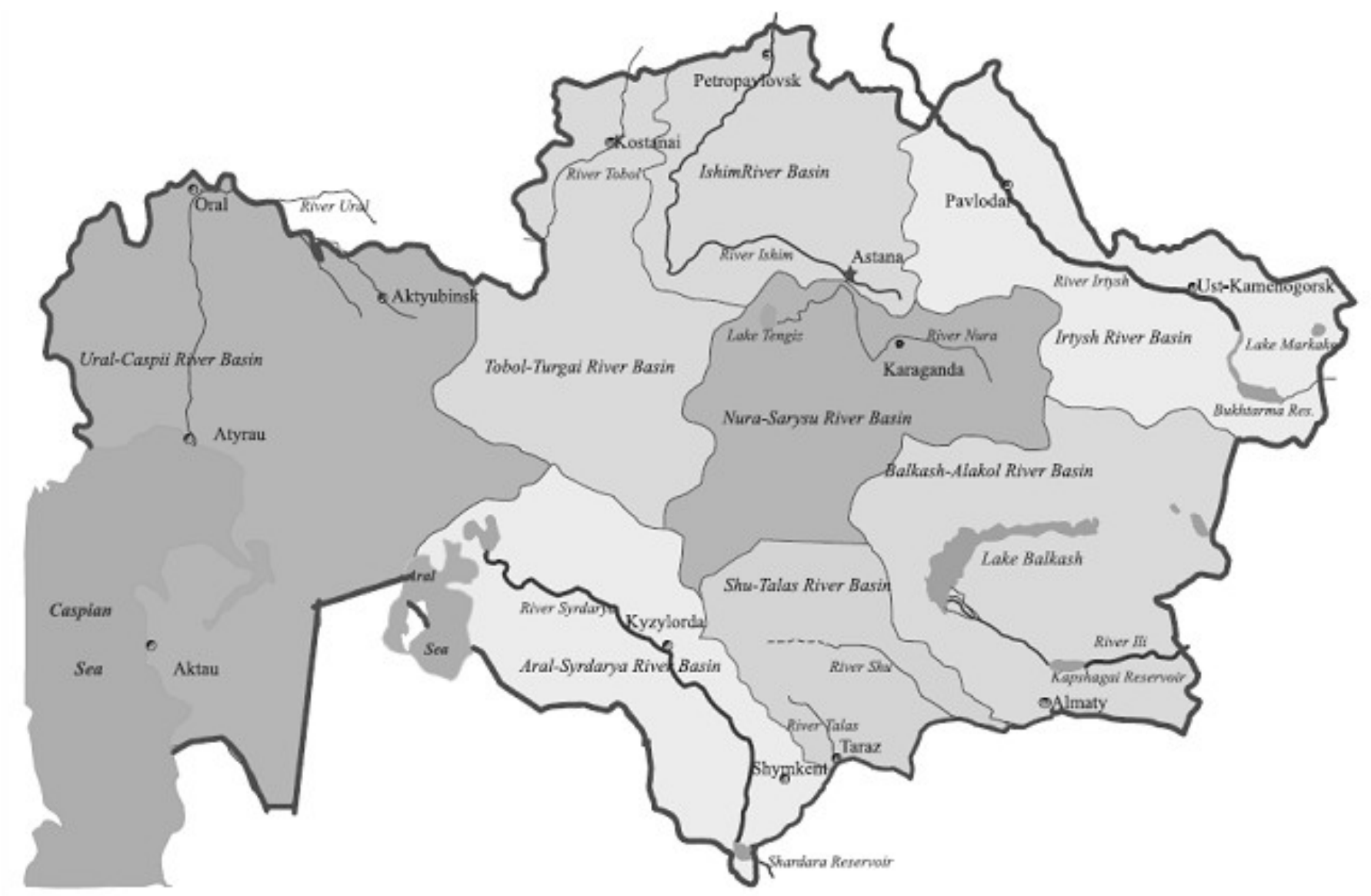

Figure 1: Map of Main River Basins in Kazakhstan ${ }^{*}$

emphasises a severe deterioration of water quality and water infrastructure across the country as a consequence of a sudden significant reduction in water sector financing (ADB 2005; Jalling 2003; Mickin 1991; OECD 2006; Petrakov et al. 2006; UNDP 2004). For example, the water infrastructure in Soviet times had been considered the most capital intensive sector. After the Soviet Union's dissolution in 1991, water infrastructure further deteriorated because of sharp decreases in public budgets and the continuing tradition of providing water virtually free of charge. An urgent increase in financing is needed to prevent collapse of water quality services and negative consequences for human health and economic activity (Petrakov et al. 2006; UNDP 2004).

Another serious reason for the deterioration of the water quality was that the 1993 WC lacked legal mechanisms and regulations. That Code neglected the environmental aspects of water management, such as water quality, watershed management, environmental flows and stakeholder involvement. The WC of 1993 was based on the Soviet water management system. The government of Kazakhstan intended to make the Water Code of 2003 as well the other laws more 'Kazakh' and less 'Soviet' (Hannan 2006; Mitrofanskaya 1999; Petrakov et al. 2006).

The period from 2000-2003 was marked by a large number of new environmental programs including "The Concept on Water Sector Development and Water Policy till 2010" (2002) which determined general Kazakhstan water policy directions, the "Drinking Water 2002-

\footnotetext{
* Map courtesy of Water Resource Committee of the Republic of Kazakhstan.
} 
2010" program, and the law on "Water User Cooperatives" 2003 (ADB 2005). All of those legislative acts prepared a base and necessity for adoption of the new WC on July 9, 2003. In addition, according to ADB (2005), all of these programs and laws have significantly strengthened the water regulation basis in Republic of Kazakhstan (RK).

In the social category for problems in WC development Petrakov et al. (2006) suggests that the rise in the level of public concern about environmental issues might have been one of the factors pushing for creation of the new WC. Jalling (2003) supports Petrakov's suggestion by stating that the political opposition on environmental issues started in the 1980s, when President Gorbachov's 'glasnost policy' opened the floor for criticism. The first outstanding example of environmental opposition in the Central Asian region was the 'NevadaSemipalatinsk' movement, organized in 1989 by the famous Kazakh poet Olzhas Suleimenov. Protesting against the nuclear tests in the Semipalatinsk region, the movement was successful, resulting in the official closure of the site in 1991. Public concern over the environment increased in the 1990s, resulting in the formation of two thousand independent non-governmental organizations (NGOs) in the Central Asian republics by the late nineties. However, these NGOs had various strengths and ranges of activities (Jelling 2003). Jelling (2003) criticizes some NGOs, especially those, supported by the United Nations and the World Bank, because their actions were considerably restricted by the governments and became additional channels for the governments' treasuries financing.

Other important factors for the new WC adoption were political and included the influence of new international declarations and principles. Tim Hannan (2006), international water management consultant, reported that the WC was partly initiated by the World Bank, which indicates significant international influence on Kazakh policy. Since the WC was written with intensive participation of international consultants, it included a considerable amount of international standards and ideas. For instance, the principle of IWRM was authorized in the WC after the World Summit in Johannesburg in 2002. Creation of River Basin Councils (RBCs), representing the new representative democratic bodies in Kazakhstan, is a significant component of IWRM definition. RBCs were authorized in the new WC and justified specifically by Kazakhstan signature of Johannesburg international declaration (Salman 2006; Kazakhstan National Report 2004; Petrakov et al. 2006).

Trans-boundary water management is a relevant issue for all Central Asian countries. This is especially relevant for Kazakhstan, which gets approximately $44 \%$ of its total average annual water resources from rivers coming from China, Uzbekistan, Kyrgyzstan and Russia (UNDP 2004). Continuous political conflicts over water became an impetus for Kazakhstan to join appropriate international conventions and to improve domestic legislation on transboundary water issues. As a result, in January 2001 Kazakhstan ratified the 1992 Helsinki Convention on the Protection and Use of Transboundary Watercourses and International Lakes (Zimina 2002). On the national level, the new Water Code included five articles in Chapter 11 on trans-boundary water regulation, substituting one article in the previous Code of 1993. The WC of 2003 provided a specific mechanism for dealing with trans-boundary water issues based on the principles of the ratified Helsinki Convention. 
Institutional factors that influenced the development of the new WC include legacies from the USSR that have been difficult to change. The Committee for Water Resources (CWR) under the Ministry of Agriculture is the central water management body in Kazakhstan. From 1990-2006 the CWR was a part of two ministries, such as Ministry of Environmental Protection and Ministry of Agriculture. Since 2002, the CWR has been functioning under the Ministry of Agriculture, which has resulted in more attention devoted to irrigation (ADB 2005; Zimina 2002). Consequently, the water sector has not been managed comprehensively. In particular, the issues of drinking water and industrial water use have been overlooked. For instance, no central government body is responsible to manage urban drinking water: it is managed only on the local level (Petrakov 2006; Syundyukov 2006). Local water management encourages competition for scarce water resources and a central management agency can direct water more equitably and consistently across time and geography. Centralized agencies can anticipate demand with population growth and build in incentives to conserve water, limit development or shift from agricultural use to domestic use. In addition to onesided responsibilities of the CWR, the attention to water issues from central government was minimal. For example, the CWR experienced a reduction of its permanent staff from 84 in 1993, to 34 people in 2003. These 34 employees were responsible for management of the entire water sector in Kazakhstan (ADB 2005). The efforts to attract support of international projects and to develop sound legislation are intended to improve the CWR capacity and to attract financing and attention to the water management sector of the country.

Despite the increasing efforts to attract attention to water issues, to date the government has financed solely infrastructure and technical weaknesses of the water sector (e.g. Drinking Water program of 2002 was aimed at building new water pipes and treatment stations); however, the programs have had little success, because of poor management and planning skills of local water managers. Therefore, staff and equipment supplies of CWR and RBOs should be increased in accordance with new functions assigned to them by the WC. Also, water managers need sufficient training in planning, water quality monitoring and other technical skills to be able to successfully enforce new water programs.

To sum up, introduction of the new WC in 2003 was preconditioned by interconnected external and internal factors. The factors such as the sharp reduction of water sector financing, conflicts with neighboring Central Asian countries, and high involvement of international organizations, were connected to the disintegration of the USSR and sudden independence of Kazakhstan in 1991. The other factors such as rapid economic development, rising public concern about environmental issues, intensive development of the legislative base, and weak institutional capacity of water management organizations, are related to the internal policies of the country during the period of 1991-2003. Consequently, the new WC had to account for all these factors and demands to be adopted and be feasible to implement.

\section{Features of the Water Code of 2003}

The central goal of the WC was to achieve and maintain an environmentally safe and economically efficient level of water use and to protect water resources in order to preserve and improve the living conditions of citizens (Water Code 2003). First, the strengths and innovations of the WC will be discussed and then its major limitations will be examined. 
There are six main goals of the Water Code of 2003: a) clarify and expand the competencies of governmental water management bodies; b) clarify and regulate water property issues; c) clarify the types of the allowable water use; d) prioritize environmental standards in water management; e) detail the issue of trans-boundary water use and regulation; and f) adopt the National IWRM Plan as the key WC enforcement mechanism.

In terms of its innovations, the WC integrated the international standards on equitable access to water resources and authorized the principles of IWRM in Kazakhstan. An essential component of IWRM is public participation. Therefore, the WC incorporated public participation by creating RBCs. According to Hannan, one reason for the working group's decision to introduce RBCs in Kazakhstan was the lack of public participation in the initial process of the WC development. Besides RBCs, several other important concepts of ownership and management of water infrastructure were introduced, such as hydroameliorative condominiums ${ }^{*}$ and water servitude ${ }^{\dagger}$ (Zimina 2002). The innovative policy allowed for private and shared ownership of the land and water infrastructure in contrast to pure governmental property ownership in Soviet times.

It is also important to mention that the WC is a much more detailed piece of legislation than the old WC. This indicates that stakeholders have realized the complexity of the issue and the continuing problem of inefficient and inadequate water management in the country. Water law evolves with experience, time and continued evaluation of successes and failures in implementation.

Although the new WC had significant advantages, it has received criticism on several fronts: 1) there is no clarity in the functions of Committee for Water Resources (CWR); 2) the role of NGOs and public organizations in decision-making process is not given enough attention; 3) the definition is unclear about the responsibility of drinking water suppliers in front of primary water users (Kazakhstan National Report 2004); 4) there is some inconsistency of the WC with other legislative acts.

The lack of clarity in the role of CWR is due to the fact that its deputy head and the heads of other departments are principal state inspectors for water consumption and preservation, as well as key executors of water policy (Zimina 2002). This lack of differentiation leads to conflict between central agency executives and the water organizations. Public participation, accounted for in the new WC by introducing the basin councils, was not enough. Participation was accounted for in the WC very insufficiently, formulated as "public organizations representatives may become members of basin council" (Water Code 2003). Moreover, councils were not given decision-making power; they only had a consultative role, thereby diminishing their role in encouraging public involvement. In addition, the WC did not provide any regulations in terms of responsibilities and rights in drinking water supply sector. In particular, there is no provision in the WC that would specify the responsibility of water

\footnotetext{
* Hydro-ameliorative condominiums are defined as "a special form of ownership whereby lands are in private ownership of natural and artificial persons, and water infrastructure belongs to them as a communal share property" (Water Code 2003)

${ }^{+}$Water servitude is the right to limited exploitation of a water unit (Zimina 2002).
} 
users to pay for the water supply services. This limitation of the new WC can be explained by the fact that CWR currently functions under the Ministry of Agriculture, which is not directly interested in drinking water issues. Such drawbacks in the regulation are important factors that result in the low level of drinking water supply - only $60 \%$ of Kazakhstan' population has regular access to drinking water. Finally, the inconsistency with other legislative acts mainly lies in the fact that the principles of IWRM are not integrated into the relevant laws, including Civil Code, Law on Taxation, environmental protection laws and other appropriate laws (Hannan 2006).

\section{Social process of the WC development}

Kazakhstan is a new independent state that emerged from the Soviet command-and-control regime. The government does not have much experience in stakeholder involvement. The concept of public participation is still in the stage of formulation and adaptation. The major stakeholders in the WC development were CWR, River Basin Organizations (RBOs) and representatives from all interested Ministries, such as Ministry for Environmental Protection, Ministry of Finance, Ministry of Economy and Budget Planning and others. In addition, since Water Code was being developed within the international project, funded by UK Department for International Development (DFID), there were not many of public organizations involved. To improve public involvement in the issue, the project organized several stakeholder workshops with some environmental NGOs and various press representatives, and "quite a few 'local people' that we practically dragged off the street" (Hannan 2006).

\section{Status of the Water Code enforcement}

Based on the interview results with Petrakov and Hannan, the key developers of the WC, the Code is not being implemented. Petrakov considers the main challenges to the WC implementation to be: 1) a lack of awareness and understanding of the new legislation among public officials; 2 ) an inadequate institutional capacity to perform assigned functions; and, 3) a lack of appropriate financing in the water sector. Hannan, asserts, however, that the main reason for slow WC implementation is inconsistency of other legislative acts with water legislation. The other codes and laws contradict the WC, according to Hannan, because they do not yet integrate IWRM principles. The fact that during the period from 1999 to 2004 the parliament of Kazakhstan adopted 566 laws does not necessarily show the improvement of the quality of legislative system. Although Tuyakbai Zh., chairman of Mazhilis (lower chamber of Kazakhstan' parliament), asserted in 2004 that this number of laws passed indicates the sustainable development of legislative system in the country, some policy experts argue that this overwhelming number of legislative documents has left significant contradictions among new and old laws (Kazakhstan Today 2004; OECD 2000).

The concept of River Basin Councils introduced as public involvement in water management process, was completely new for water managers in Kazakhstan. This unfamiliarity with the concept of public participation is related to Soviet expert-centered policy-making process, which excluded main stakeholders from participation (OECD 2000).

The limited capacity of water management authorities and the lack of sufficient financing leads to a general slowness and inactivity of the government to enforce the Water Code. Therefore, to assist the government of Kazakhstan, UNDP Project in coordination with CWR is 
developing a National IWRM Plan, the adoption of which will become a significant step towards the WC implementation. National IWRM Plan is aimed at providing practical steps and actions towards ensuring effective and integrated water resource management at the national and river basin levels (UNDP 2005).

\section{Conclusion and recommendations}

The creation of the new Water Code in 2003 was a significant improvement in Kazakhstan's water legislation. The development of the new WC was necessary because of financial, legal, social, political and institutional changes, which occurred after the separation from the Soviet rule. The key factor in the water degradation, which undermined all other spheres, was the reduction of financial support in the water sector of the country. The reduction of funds led to the deterioration of water quality and infrastructure, the weakening of water management body's capacity, increased potential for trans-boundary river conflicts and rising public concern about the status of water and environment in the country.

The WC development process was initiated in part by the World Bank and in part by CWR. The initial development was dominated by both international and local policy experts, while little participation was observed from environmental NGOs and the media. Because the WC was developed within the international project, several important points in the Code were formulated according to international standards and it was challenging for local officials to understand and appropriately implement those provisions.

There are three main recommendations to the government of Kazakhstan to improve water regulation. First, higher funding should be provided to the water sector and directed at strengthening the water management institutions in order to develop clear strategies and increase the commitment of implementing organizations (OECD 2000). Second, more consistency should be established among the legislative acts. In particular, principles of IWRM should be integrated into the relevant laws, including the Civil Code, the Law on Taxation, and environmental protection laws. The WC should be amended as well to clarify functions of central water management bodies and to strengthen the role of River Basin Councils. Finally, a better information network should be established among water management organizations to distribute more information on the new WC provisions and other water programs among key local executives. For example, more explanation about the role and meaning of River Basin Councils, as well as other new water ownership concepts is required to ensure their successful realization on the local level.

Looking into the near future, there are two likely scenarios in which the water resources sector could be developed. The first scenario assumes the continuing inactivity and delay on the side of the government. In this case, due to further deterioration of water quality and infrastructure there will be a quick increase in public concern and participation. Failure to implement WC provisions may cause increasing water conflicts with neighboring countries because of the lack of accurate water quality monitoring in Kazakhstan and poor negotiations skills. One of the channels for public involvement in decision-making may become the newly formed Basin Councils and a subsequent increasing influence of NGOs. Eventually, the government will have to improve the existing policy. 
The second scenario is more optimistic and it assumes that CWR will gain higher status either within the agency or the ministry. The government will start undertaking active steps towards the WC enforcement and devote more attention and financial resources to water sector in the next two years. Also, more attention will be devoted in Kazakhstan to improving the institutional capacity of executive bodies, rather than "patching the holes" in the old system. In this case there is the potential to improve management both of irrigation and of drinking water supply. The only thing that Kazakhstan needs is greater political will to improve the system of water management.

In conclusion, Kazakhstan needs to adopt and start implementing National IWRM plan, developed with the assistance of UNDP IWRM project, to make a necessary step towards the improvement of internal water resource management and to move closer towards the resolution of trans-boundary water issues. For instance, improving managerial and negotiation skills of RBOs together with strengthening their institutional and technical capacity would result in their greater ability to resolve conflicts and come to an agreement on the local level.

\section{References}

Asian Development Bank, 2005, Improving institutional capacity of Committee for water resources in the Republic of Kazakhstan, TA № 4484 KAZ, Almaty, Kazakhstan.

Concept on Water Sector Development and Water Policy till 2010 2002, \#71

Dinar, A 2004, Institutional Economics of Water: A Cross-Country Analysis of Institutions and Performance. Herndon, VA, USA: World Bank, viewed 20 October, 2006, http://site.ebrary.com/lib/nau/Doc?id=10058813\&ppg=18

Everett-Heath, T 2003 Central Asia: Aspects of transition. New York and London: RoutledgeCurzon.

Jalling, L 2003, 'Environmental issues in Central Asia. A source of hope or despair?' Central Asia: Aspects of transition. New York and London: RoutledgeCurzon.

Jones, N 2003, 'South Aral Sea 'gone in 15 years". New Scientist Print Edition, viewed 19 January, 2006, http://www.newscientist.com/article.ns?id=dn3947

Kazakhstan National Report 2004, О состоянии водных ресурсов и основные проблемы современного управления. Часть 4: Юридические и административные аспекты. [Situation with water resources and major problems with current management Seminar on the role of ecosystems as water suppliers. Chapter 4: Legal and administrative aspects, pp. 21-26, Geneva December 13-14, viewed 6 October, 2006, http://www.unece.org/env/water/meetings/ecosystem/Reports/Kazakhstan_ru.pdf

Mickin, PP 1991, 'The water management crisis in Soviet Central Asia', The Carl Beck Papers in Russian and East European Studies, no. 905, University of Pittsburgh: Center for Russian and East European Studies.

Mickin, PP 2000, 'Managing water in Central Asia', Central Asian and Caucasian prospects, Great Britain: Chameleon press. 
Mitrofanskaya,Y, Bideldinov, D 1999, 'Modernizing Environmental Protection in Kazakhstan', Georgetown International Environmental Law Review, 12 Geo. Int'I Envtl. L. Rev. 177

Organization for Economic Co-operation and Development 2000, Environmental regulatory reform in the NIS: the case of the water sector, Twelfth meeting of the EAP task force, viewed 4 October, 2006, http://www.oecd.org/dataoecd/62/13/1876109.pdf

Organization for Economic Co-operation and Development 2006, Financing water and environment infrastructure. The case of Eastern Europe, the Caucasus and Central Asia, 75006 Paris, France

Petrakov, IA 2006, Правовые аспекты сектора водоснабжения и канализации [Legal aspects of water supply and sanitation sectors], paper presented at the Seminar on water supply and sanitation systems development in the Republic of Kazakhstan until 2015, Astana, Kazakhstan, viewed 19 January, 2006, http://www.voda.kz/new/doc_seminar_2015.php

Petrakov, Alyahasov \& Nikolayenko 2006, Управление водными ресурсами в Казахстане - история, анализ, сравнения, таблицы, схемы, рекомендации (взгляд независимых экспертов) [Water Resources Management in Kazakhstan: history, analysis, comparisons, tables, schemes, recommendations (view of independent experts)], International project, Almaty, Kazakhstan.

Pilipiyuk, O 2003, 'Откуда набрать водицы для законотворцев [Where to get water from for lawmakers]', Kazakhstan Today 11 April, 2003.

Project of United Nations Development Program and Committee for Water Resources 2005, National integrated water resource management and water efficiency plan: the first draft, UNDP, viewed 15 September 15, 2006, http://www.voda.kz/new/en/doc/doc_plan.pdf

Salman, MA 2006, Regulatory Frameworks for Water Resources Management: A Comparative Study. Herndon, VA, USA: World Bank, viewed 28 September, 2006, http://site.ebrary.com/lib/nau/Doc?id=10124810\&ppg=13

Syundyukov, V 2006, Состояние систем водоснабжения и водоотведения в Республике Казахстан [Current conditions of water supply and sanitation in the Republic of Kazakhstan], paper presented at the Seminar on water supply and sanitation systems development in the Republic of Kazakhstan until 2015, Astana, Kazakhstan, viewed 19 January, 2006, http://www.voda.kz/new/doc_seminar_2015.php

United Nations Development Program 2004, Water Resources in Kazakhstan in the New Millennium, UNDPKAZ 07, Almaty, Kazakhstan, viewed 25 October, 2006, http://www.undp.kz/library_of_publications/files/2496-19223.pdf

Water Code of the Republic of Kazakhstan 2003, last amended in 7 July 2006.

Zimina, L 2002, 'Developing water management in South Kazakhstan' Water Management in the Southern Caucasus and Central Asia, viewed 20 November, 2006, www.transcend.org/t_database/pdfarticles/182.pdf 
